\title{
CASE OF INDIGENOUS COMMUNITIES KUNA OF MADUNGANDÍ AND EMBERÁ OF BAYANO AND ITS MEMBERS V. PANAMA*
}

\author{
CASO DE LOS PUEBLOS INDÍGENAS \\ KUNA DE MADUNGANDÍ Y EMBERÁ DE \\ BAYANO Y SUS MIEMBROS VS. PANAMÁ
}

Andrés SARmiento-LAmus**

Reception date: June $25^{\text {th }}, 2015$ Acceptance date: September $8^{\text {th }}, 2015$ Available online: November $30^{\text {th }}, 2015$

\begin{abstract}
TO CITE THIS ARTICLE / PARA CITAR ESTE ARTÍCUlO Sarmiento-Lamus, Andrés, Case of Indigenous Communities Kuna of Madungandí and Emberá of Bayano and its Members v. Panama, 27 International Law, Revista Colombiana de Derecho Internacional, 9-38 (2015). http://dx.doi.org/10.11144/Javeriana.i115-27.cick
\end{abstract}

doi:10.11144/Javeriana.i115-27.cick

* Reflexion article supported by the Law School of Sergio Arboleda University / Artículo de reflexión que cuenta con el apoyo de la Universidad Sergio Arboleda y su Escuela de Derecho.

** PhD candidate, Leiden University (The Netherlands). Researcher, School of Law, Universidad Sergio Arboleda. Member of the Colombian Academy of International Law. Contact: andres.sarmiento@usa.edu.co 


\begin{abstract}
The judgment of 14 October 2014 in the Case of Indigenous Communities Kuna of Madungandi and Emberá of Bayano and its members v. Panamá, concerned the alleged international responsibility of Panama for, inter alia, the continuous violation of the right to collective property of the indigenous communities due to the failure to compensate them for stripping and flooding of their territories, for the construction of a hydroelectric dam. The Inter-American Court of Human Rights decided in its judgment to be without jurisdiction ratione temporis to proceed to the merits of this claim. The article argues the decision of the Inter-American Court of $\mathrm{Hu}-$ man Rights was incorrect from the standpoint of the continuous violations doctrine, as well as it argues that the Inter-American Court of Human Rights missed a unique opportunity to set forth the scope of its jurisdiction ratione temporis with regard to expropriations and the obligations deriving from it for States. Therefore, an appraisal and acknowledgment of judge Ferrer Mac-Gregor Poisot partial dissenting opinion is made, as sole dissenter in this aspect of the judgment.
\end{abstract}

Keywords: Jurisdiction ratione temporis; continuous violations; right to property; compensation 
La sentencia del 14 de octubre de 2014 en el caso de los Pueblos Indígenas Kuna de Madungandí y Emberá de Bayano y sus miembros vs. Panamá, hace referencia a la responsabilidad internacional por parte de Panamá por, inter alia, la violación continuada del derecho a la propiedad colectiva de las comunidades indígenas, debido a la falta de compensación por el despojo e inundación de sus territorios para la construcción de una hidroeléctrica. En su sentencia, la Corte Interamericana de Derechos Humanos decidió no considerarse competente ratione temporis para analizar el fondo de esta pretensión. Este escrito argumenta que la decisión de la Corte Interamericana de Derechos Humanos fue incorrecta a la luz de la doctrina de las violaciones continuadas, y sostiene que la Corte Interamericana de Derechos Humanos perdió una oportunidad única para establecer el ámbito de su competencia ratione temporis respecto a las expropiaciones y las obligaciones que de estas derivan para los Estados. Por lo tanto, se realiza una valoración y reconocimiento al voto parcialmente disidente del juez Ferrer Mac-Gregor Poisot, como único juez disidente en este aspecto de la decisión.

Palabras clave: Jurisdicción ratione temporis; violaciones continuadas; derecho a la propiedad; compensación.

\section{SUMMARY}

InTRODUCTION.- I. FACTUAL BACKGRound.- II. CONTINUOUS Violations UndeR International Law.- $A$. The International Law Commission.- B. Investment Tribunals.- C. Human Rights Bodies.- 1. Human Rights Committee.- 2. European Court of Human Rights.- III. The Courts' Decision to Uphold Panama's Preliminary Objection.- A. The Reasoning of the Court.- B. Judge Ferrer Mac-Gregor partial dissenting opinion.- CONCLUSION.- BIBLIOGRAPHY. 
INTRODUCTION

On 14 October 2014, the Inter-American Court of Human Rights (hereinafter referred as "the Court" or "the IACtHR") rendered its judgment in the Case of Indigenous Communities Kuna of Madungandí and Emberá of Bayano and their Members v. Panama. ${ }^{1}$ The applicants complained for the alleged international responsibility of Panama concerning (i) the continuous violation of the right to collective property of the indigenous communities due to the failure to compensate them for the stripping and flooding of their territories, for the construction of a hydroelectric dam from 1972 to 1976; (ii) the lack of recognition, granting deeds and demarcation of lands given to the complainants after the construction of the hydroelectric; (iii) the lack of effective protection of their territory and natural resources from third-parties; (iv) the failure of Panama to provide an adequate and effective remedy allowing access to their property and avoiding interference from third-parties; and (v) the discrimination against the Kuna and Emberá communities by means of certain laws enacted by Panama and which are still in force. ${ }^{2}$

In its judgment, the Court by five votes to one, decided to uphold Panama's second preliminary objection concerning its lack of jurisdiction ratione temporis (which specifically referred to claim (i) above) while unanimously dismissing the first and third preliminary objections. ${ }^{3}$ As for the merits, the Court unanimously declared that Panama had violated Articles 8.1 (right to a fair trial), 21 (right to property), and 25 (right to judicial protec-

1 Inter-American Court of Human Rights, IACtHR, Case of Indigenous Communities Kuna of Madungandí and Emberá of Bayano and their Members v. Panama, Series C 284, Preliminary objections, merits, reparations and costs, Judgment of 14 October 2014. Available at: http://www.corteidh.or.cr/docs/casos/articulos/seriec_284_esp.pdf

2 Inter-American Court of Human Rights, IACtHR, Case of Indigenous Communities Kuna of Madungandí and Emberá of Bayano and their Members v. Panama, Series C 284, Preliminary objections, merits, reparations and costs, Judgment of 14 October 2014, para. 1. Available at: http://www.corteidh.or.cr/docs/casos/articulos/seriec_284_esp.pdf

3 Panama's first preliminary objection addressed the complainants' failure to exhaust all local remedies available. The third preliminary objection as to the IACtHR's lack of jurisdiction was based on the prescription of the right to claim the alleged pending payment of compensation for the loss of their territories. 
tion) in relation to Articles 1.1 and 2 of the American Convention on Human Rights ${ }^{4}$ (hereinafter referred as "ACHR"), for three reasons: First, the failure to delimitate, demarcate, and grant deed over lands of the indigenous communities; second, the absence of internal laws before 2008 with regard to delimitation, demarcation and granting deed; and third, the breach of the reasonable time with respect to certain internal proceedings.

In a powerful partial dissenting opinion, Judge Eduardo Ferrer Mac-Gregor Poisot expresses his disagreement with the majority of the Court concerning the decision to uphold Panama's second preliminary objection. ${ }^{5}$ Based on said dissenting opinion, this article seeks to analyse the IACtHR's jurisdiction ratione temporis in the context of expropriations and continuous violations of human rights. It will first give an overview of the relevant factual background to the case in section I. In section II, this article will set out the scope of continuous violations under international law, with special emphasis on expropriations. Further, section III will refer to the Court's decision to upheld Panama's preliminary objection and the dissenting opinion appended by Judge Ferrer Mac-Gregor. Lastly, in section IV and as conclusion, this article will provide an analysis with respect to both, the IACtHR's decision and its jurisdiction ratione temporis in the case of expropriations taking place before states have either ratified the ACHR or accepted the contentious jurisdiction of the Court. Likewise, a comment will be made as to the importance of judge Ferrer Mac-Gregor Poisot partial dissenting opinion.

4 Organization of American States, OAS, American Convention on Human Rights, Pact of San Jose, Costa Rica, 22 November 1969. Available at: http://www.oas.org/dil/ treaties_B-32_American_Convention_on_Human_Rights.htm

5 Inter-American Court of Human Rights, IACtHR, Case of Indigenous Communities Kuna of Madungandi and Emberá of Bayano and their Members v. Panama, Series C 284, Judgment of 14 October 2014, partial dissenting opinion of Judge Eduardo Ferrer Mac-Gregor Poisot. Available at: http://www.corteidh.or.cr/docs/casos/articulos/seriec_284_esp.pdf 


\section{FACTUAL BACKGROUND}

The indigenous community Kuna of Madungandí inhabited the Bayano region since the $16^{\text {th }}$ century. On the other hand, the indigenous community Emberá of Bayano inhabited in the same region since the $19^{\text {th }}$ century. ${ }^{6}$ In 1963 , Panama and the United States Agency for International Development, USAID, proposed a project consisting in the construction of a hydroelectric complex in the Bayano region, which required the creation of a reservoir of $350 \mathrm{~km}^{2}$. Consequently, by the enactment of the Decree 123 of May 8, 1969 (and in order to perform said project), Panama recognised its duty to relocate all the inhabitants of the region where the project would be carried out. In addition, and considering this relocation involved the loss of the land, crops, and animals of the indigenous communities, Panama enacted the Cabinet Decree 156 of 1971 deciding to grant them economic compensation. In 1972, Panama began the construction of the hydroelectric dam and from 1973 to 1975 the relocation of the indigenous communities of Kuna of Madungandí and Emberá of Bayano took place. Due to the lack of payment of the economic compensation as of 1977, an agreement (the Fuerte Cimarrón agreement) was signed with the indigenous community Kuna of Madungandí, establishing a new timetable to comply with said payments. Lastly, and due to a new event of failure to comply with the payment of the economic compensation, a new agreement (signed by Panama's vice president Ricardo de La Espriella) was signed in 1980 .

Throughout this time and up until the petition was presented before the Inter-American Commission on Human Rights, on 11 May 2000, the indigenous communities initiated certain legal

6 Inter-American Court of Human Rights, IACtHR, Kuna Indigenous People of Madungandí and Emberá Indigenous People of Bayano and their Members v. Panamá, Case 12354, Merits, Report 125/12, para. 57. Available at: http://www.oas.org/en/iachr/decisions/ court/12.354FondoEng.pdf

7 Inter-American Court of Human Rights, IACtHR, Kuna Indigenous People of Madungandi and Emberá Indigenous People of Bayano and their Members v. Panamá, Case 12354, Merits, Report 125/12 para. 17. Available at: http://www.oas.org/en/iachr/decisions/ court/12.354FondoEng.pdf 
proceedings seeking to, inter alia, obtain the payment of the economic compensation.

Having ratified the ACHR on 5 June 1978, and accepting the Court's contentious jurisdiction on 9 May 1990, Panama argued before the Inter-American Commission of Human Rights and the Court, their lack of jurisdiction ratione temporis since the expropriation of the indigenous communities' lands took place before any conventional obligations existed in this regard. ${ }^{8} \mathrm{On}$ the other hand, the complainants and the Inter-American Commission of Human Rights maintained the lack of payment of compensation constitutes a continuous violation of their right to property. ${ }^{9}$

Based on the parties' arguments in this regard, the next section will set out the scope of continuous violations under international law (with special emphasis on expropriations) by referring to instances in which international courts and tribunals have dealt with this kind of situations. Reference to these instances is made with a view of introducing the topic and enriching the subsequent analysis of the Court's decision in the Case of Indigenous Communities Kuna of Madungandi and Emberá of Bayano and their Members v. Panama.

8 Inter-American Court of Human Rights, IACtHR, Kuna Indigenous People of Madungandi and Emberá Indigenous People of Bayano and their Members v. Panamá, Case 12354, Merits, Report 125/12, paras. 190-191. Available at: http://www.oas.org/en/iachr/decisions/ court/12.354FondoEng.pdf. Inter-American Court of Human Rights, IACtHR, Case of Indigenous Communities Kuna of Madungandi and Emberá of Bayano and their Members v. Panama, Series C 284, Preliminary objections, merits, reparations and costs, Judgment of 14 October 2014, para. 24. Available at: http://www.corteidh.or.cr/docs/casos/articulos/ seriec_284_esp.pdf

9 Inter-American Court of Human Rights, IACtHR, Case of Indigenous Communities Kuna of Madungandí and Emberá of Bayano and their Members v. Panama, Series C 284, Preliminary objections, merits, reparations and costs, Judgment of 14 October 2014, para. 29. Available at: http://www.corteidh.or.cr/docs/casos/articulos/seriec_284_esp.pdf 


\section{CONTINUOUS Violations Under InTERnATIONAL LAW}

\section{A. The International Law Commission}

From the early moments of the International Law Commission's (hereinafter referred as "ILC") work on the topic of state responsibility, it was acknowledged that the topic of continuous violations was of great importance, considering its significance for certain aspects on state responsibility such as, inter alia, the determination of the jurisdiction of an international tribunal as "the agreements concluded by states for this purpose often include a clause limiting the jurisdiction of the judicial or arbitral body in question to disputes concerning 'facts' or 'situations' subsequent to a specific date."10

From the work made by the ILC for more than four decades, which concluded in the presentation of draft articles to the General Assembly of the United Nations, two provisions deal with the matter of continuous violations. Article 13 establishes an act of a state does not entail the breach of an international obligation unless the state is bound by said obligation when the act occurs. ${ }^{11}$ As for Article 14, it defines an instantaneous act as the violation of an international obligation occurring when the act is taking place, although the effects of the breach continue. ${ }^{12}$ Additionally, when the violation consists of a continuous act, the breach of the international obligations extends over the entire period of time the act extends. ${ }^{13}$

10 Seventh Report on State Responsibility by Mr. Roberto Ago, Special Rapporteur - The Internationally Wrongful Act of the State, source of international responsibility, Yearbook of the International Law Commission 1978, Volume II (part one), A/CN.4/SER.A/1978/ Add.1 (Part 1), 38, para. 23. Available at: http://legal.un.org/docs/?path=../ilc/publications/ yearbooks/english/ilc_1978_v2_p1.pdf\&lang=EFSR

11 Draft Articles on Responsibility of States for Internationally Wrongful Acts, Yearbook of the International Law Commission 2001, Volume II (part two), A/CN.4/SER.A/2001/ Add.1 (Part 2), 57. Available at: http://legal.un.org/ilc/publications/yearbooks/english/ ilc_2001_v2_p2.pdf

12 Draft Articles on Responsibility of States for Internationally Wrongful Acts, Yearbook of the International Law Commission 2001, Volume II (part two), A/CN.4/SER.A/2001/ Add.1 (Part 2), 59. Available at: http://legal.un.org/ilc/publications/yearbooks/english/ ilc_2001_v2_p2.pdf

13 Draft Articles on Responsibility of States for Internationally Wrongful Acts, Yearbook 
In its commentary to these articles, the ILC notes that the determination of when a violation is instantaneous or continuous is to be made on a case by case basis, i.e., in light of the content of the obligation and the circumstances in which the violation occurs. ${ }^{14}$ Similarly, it reiterates what is explicitly noted in the wording of draft article 14, namely, that extension in time of the effects of a breach does not have any bearing in the determination whether the act has a continuous character. ${ }^{15}$

An example of the situation above is, for the ILC, the act through which an expropriation is carried out. When the said expropriation is direct, it constitutes an instantaneous violation. ${ }^{16}$ This is so, since the content of the obligation not to expropriate refers as to the prohibition for the state, not to cancel the deed. Once the deed has been revoked, the state has breached its obligation, although the effects continue. As the ILC itself noted,

An act does not have a continuing character merely because its effects or consequences extend in time... the economic effects of the expropriation of property continue even though... the title to property has passed. Such consequences are the subject of the secondary obligations of reparation... they do not, however, entail that the breach itself is a continuing one. ${ }^{17}$

of the International Law Commission 2001, Volume II (part two), A/CN.4/SER.A/2001/ Add.1 (Part 2), 59. Available at: http://legal.un.org/ilc/publications/yearbooks/english/ ilc_2001_v2_p2.pdf

14 Draft Articles on Responsibility of States for Internationally Wrongful Acts, Yearbook of the International Law Commission 2001, Volume II (part two), A/CN.4/SER.A/2001/ Add.1 (Part 2), 60, para. 4. Available at: http://legal.un.org/ilc/publications/yearbooks/ english/ilc_2001_v2_p2.pdf

15 Draft Articles on Responsibility of States for Internationally Wrongful Acts, Yearbook of the International Law Commission 2001, Volume II (part two), A/CN.4/SER.A/2001/ Add.1 (Part 2), 59, para. 2. Available at: http://legal.un.org/ilc/publications/yearbooks/ english/ilc_2001_v2_p2.pdf

16 Draft Articles on Responsibility of States for Internationally Wrongful Acts, Yearbook of the International Law Commission 2001, Volume II (part two), A/CN.4/SER.A/2001/ Add.1 (Part 2), 60, para. 4. Available at: http://legal.un.org/ilc/publications/yearbooks/ english/ilc_2001_v2_p2.pdf

17 Draft Articles on Responsibility of States for Internationally Wrongful Acts, Yearbook of the International Law Commission 2001, Volume II (part two), A/CN.4/SER.A/2001/ Add.1 (Part 2), 60, para. 6. Available at: http://legal.un.org/ilc/publications/yearbooks/ english/ilc_2001_v2_p2.pdf 


\section{B. Investment Arbitral Tribunals}

Some arbitral tribunals have analysed its jurisdiction ratione temporis in relation to the continuous violations doctrine. The majority of these tribunals have done it, based on the ILC articles on state responsibility. Their findings in this regard are useful for the subsequent discussion of the case under analysis.

In Mondev International Ltd. v. USA, the arbitral tribunal when assessing an alleged violation of the obligation not to expropriate, concluded it lacked jurisdiction to analyse the merits of this allegation. It considered expropriation as an instantaneous act that, moreover, took place before the treaty entered into force. Compliance or not with the payment of compensation is only relevant therefore for the characterization of the expropriation as either legal or illegal..$^{18}$ In accordance thus with the Vienna Convention on the Law of Treaties, ${ }^{19}$ "the mere fact that earlier conduct has gone unremedied or unredressed when a treaty enters into force does not justify a tribunal applying the treaty retrospectively to that conduct." ${ }^{20}$ Subsequent arbitral tribunals have consistently applied this reasoning, in order to conclude that they have jurisdiction over events subsequent to the entry into force of the treaty. ${ }^{21}$

18 International Centre for Settlement of Investment Disputes, ICSID, Mondev International Ltd. v. United States of America, ARB(AF)/99/2, Award of 11 October 2002, para. 71. Available at: http://www.italaw.com/sites/default/files/case-documents/ita1076.pdf

19 "Unless a different intention appears from the treaty or is otherwise established, its provisions do not bind a party in relation to any act or fact which took place or any situation which ceased to exist before the date of the entry into force of the treaty with respect to that party." United Nations, UN, Vienna Convention on the Law of Treaties, done at Vienna on 23 May 1969, entered into force on 27 January 1980, vol. 1155 UNTS, article 28 (Treaty Series, United Nations, New York, Geneva, 1969). Available at: http:// legal.un.org/ilc/texts/instruments/english/conventions/1_1_1969.pdf

20 International Centre for Settlement of Investment Disputes, ICSID, Mondev International Ltd. v. United States of America, ARB(AF)/99/2, Award of 11 October 2002, para. 70. Available at: http://www.italaw.com/sites/default/files/case-documents/ita1076.pdf

21 International Centre for Settlement of Investment Disputes, ICSID, MCI Power Group, L.C. and New Turbine, Inc. v. Ecuador, ARB/03/6, Award of 31 July 2007, paras. 84 and 93. Available at: http://www.italaw.com/sites/default/files/case-documents/ita0500.pdf. International Centre for Settlement of Investment Disputes, ICSID, Railroad Development Corporation v. Guatemala, ARB/07/23, Second Decision on Objections to Jurisdiction, Decision of 18 May 2010, para. 124. Available at: http://www.italaw.com/sites/default/ files/case-documents/ita0704.pdf. United Nations Commission on International Trade Law, UNCITRAL, Sergei Paushok CJSC Golden East Company \& CJSC Vostokneftegaz 
Nonetheless, and based on the same reasoning, acts such as the lack of payment of certain sums of money deriving from a contract signed before the treaty entered into force, ${ }^{22}$ undue delay from internal tribunals in providing justice before and after the treaty entered into force, ${ }^{23}$ and the omission to grant concessions and mining permits, ${ }^{24}$ have been considered as continuous acts. The reason for characterising these situations as continuous acts (compared to an expropriation) is based on the content of the obligation. In this sense, it is the continuation in time, not only of the effects of the breach but of the breach itself, which makes the act to be considered a continuous violation.

From all the above-mentioned decisions derive the idea (concordant with that expressed by the ILC) that both, the internationally wrongful act and its consequences should occur (even partially) after the treaty has entered into force. As expressly noted in its preliminary objections decision by the arbitral tribunal in Société Générale in respect of DR Energy Holdings Limited and Empresa Distribuidora de Electricidad del Este, S.A. v. Dominican Republic,

an act [might be] continuous but its legal materialization as a breach occurs when the Treaty has come into force... Thus, there is no strict issue of retroactive application of the treaty concerned, and Article 28 of the Vienna Convention is not implicated. If it is merely the continuous effects of a onetime individual act that as such has ceased to exist that is involved, then the non-retroactivity principle fully applies, but when both the existence of the wrongful act and its effects continue both before and after the critical

Company v. Mongolia, Award on Jurisdiction and Liability, Decision of 28 April 2011, para. 498. Available at: http://www.italaw.com/sites/default/files/case-documents/ita0622. pdf

22 International Centre for Settlement of Investment Disputes, ICSID, SGS Société Générale de Surveillance S.A. v. Philippines, ARB/02/6, Decision on Jurisdiction, Decision of 29 January 2004, para. 167. Available at: http://www.italaw.com/cases/1018, http://www. italaw.com/sites/default/files/case-documents/ita0782.pdf

23 United Nations Commission on International Trade Law, UNCITRAL, Chevron Corporation (USA) \& Texaco Petroleum Corporation (USA) v. Ecuador, Paris Court of Appeal, PCA Case 34877, Interim Award of 1 December 2008, para. 298. Available at: http://www. italaw.com/documents/Chevron-TexacovEcuadorInterimAward.pdf

24 International Centre for Settlement of Investment Disputes, ICSID, Pac Rim Cayman LLC v. El Salvador, ARB/09/12, Decision on Jurisdictional Objections of 1 June 2012, para. 2.94. Available at: http://www.italaw.com/sites/default/files/case-documents/ita0935. pdf 
date, then the non-retroactivity principle will not exclude the application of the obligations of the treaty to acts and omissions that occur after its effective date. ${ }^{25}$

\section{Human Rights Bodies}

\section{Human Rights Committee}

The Human Rights Committee (hereinafter referred as "HRC") has noted the obligations of a state party to the International Covenant on Civil and Political Rights are enforceable on the date the treaty enters into force for the said state. ${ }^{26}$ This, however, is not sufficient to examine individual petitions in accordance with the First Optional Protocol. ${ }^{27}$ The HRC is competent ratione temporis therefore with regard to violations occurring after both instruments have been ratified by a state.

This principle has also been applied in the context of continuous violations. ${ }^{28}$ The HRC has moreover noted that a violation of this kind should be interpreted as an affirmation, after the entry into force of the optional protocol by act or clear implication, of the previous violations of the state party. ${ }^{29}$ It is against this

25 United Nations Commission on International Trade Law, UNCITRAL, Société Générale in respect of DR Energy Holdings Limited and Empresa Distribuidora de Electricidad del Este, S.A. v. Dominican Republic, London Court of International Arbitration, LCIA Case UN 7927, Preliminary Objections to Jurisdiction, Decision of 19 September 2008, para. 88. Available at: http://www.italaw.com/sites/default/files/case-documents/ita0798.pdf

26 Kerem Altiparmak, The Application of the Concept of Continuing Violation to the Duty to Investigate, Prosecute and Punish International Human Rights Law, 21-25 Turkish Yearbook of Human Rights, 3-50, 4 (1999-2004). Available at: http://papers.ssrn.com/sol3/papers. cfm?abstract_id $=926281$

27 United Nations, UN, Optional Protocol to the International Covenant on Civil and Political Rights, adopted and opened for signature, ratification and accession by General Assembly resolution 2200A (XXI) of 16 December 1966, entry into force 23 March 1976, in accordance with Article 9, volume 999 UNTS, 302, article 1 (Treaty Series, United Nations, New York, Geneva, 1976). Available at: http://www.ohchr.org/EN/ProfessionalInterest/ Pages/OPCCPR1.aspx, https://treaties.un.org/doc/Publication/UNTS/Volume\%20999/ v999.pdf

28 Human Rights Committee under the Optional Protocol to the International Covenant on Civil and Political Rights, HRC, Patrick Holland v. Ireland, Covenant on Civil and Political Rights, UN Doc. CCPR/C/58/D593/1994, Admissibility, 8 June 1994, para. 9.2. Available at: http://www.worldcourts.com/hrc/eng/decisions/1996.10.25_Holland_v_Ireland.htm

29 Human Rights Committee under the Optional Protocol to the International Covenant on Civil and Political Rights, HRC, Simunek, Hastings, Tuzilova \& Prochazka v. Czech 
background, and in the context of expropriations, that the HRC has had the opportunity to refer to the scope of its jurisdiction ratione temporis.

In the cases of alleged violations of the right to an effective judicial remedy, sought to obtain compensation from expropriations occurring before the International Covenant on Civil and Political Rights, and its First Optional Protocol entered into force for a state, the HRC has declared the petition inadmissible. For instance, in the communication of E. and A.K. [Edith and Arpad Könye] v. Hungary, it was noted that the question whether the state failure to compensate has continuing effects, could not be answered in the affirmative. No autonomous right to compensation exist and therefore the said failure to compensate is not an affirmation of a prior violation by the state. ${ }^{30}$ Lastly, in a more recent communication, the HRC expressly noted expropriation is an instantaneous act (though with continuing effects) and thus it is precluded ratione temporis to analyse violations prior to the entry into force of both the International Covenant on Civil and Political Rights, and its First Optional Protocol. ${ }^{31}$

\section{European Court of Human Rights}

The European Court of Human Rights (hereinafter referred as "ECtHR"), unlike the HRC, has accepted (in certain situations) the continuous character of a violation of the right to property.

Republic, CCPR/C/54/D/516/1992, Views, 17 September 1991, para. 4.5. Available at: http:// www.worldcourts.com/hrc/eng/decisions/1995.07.19_Simunek_v_Czech_Republic.htm

30 Human Rights Committee under the Optional Protocol to the International Covenant on Civil and Political Rights, HRC, E. and A.K. [Edith and Arpad Könye] v. Hungary, UN Doc. CCPR/C/50/D.520/1992, Admissibility, 7 April 1994, para. 6.6. Available at: http:// www.worldcourts.com/hrc/eng/decisions/1994.04.07_E_v_Hungary.htm. This reasoning was applied too, in subsequent communications. See Human Rights Committee under the Optional Protocol to the International Covenant on Civil and Political Rights, HRC, Armand Anton v. Algeria, UN Doc. CCPR/C/88/D/1424/2005, Admissibility, 20 December 2006, para. 8.3. Available at: http://www.worldcourts.com/hrc/eng/decisions/2006.11.01_ Anton_v_Algeria.htm

31 Human Rights Committee under the Optional Protocol to the International Covenant on Civil and Political Rights, HRC, Josef Bergauer et al. v. Czech Republic, UN Doc. CCPR/C/100/D/1748/2008, Admissibility, 28 October 2010, para. 8.3. Available at: http:// www.worldcourts.com/hrc/eng/decisions/2010.10.28_Bergauer_v_Czech_Republic.pdf 
Accordingly, in cases concerning the illicit and continuous occupation from the Greek armed forces, ${ }^{32}$ the impossibility to access to property located in the northern part of Cyprus during Turkish occupation, ${ }^{33}$ and the continuous impossibility to take possession of property and obtain some money from renting it ${ }^{34}$ the ECtHR has considered these situations as continuous violations. All these cases, however, do not refer to limitations to the right to property deriving from a formal act of expropriation (i.e. direct expropriation). On the contrary, they refer to de facto restrictions imposed by the state to the right to property (i.e. indirect expropriation).

In cases concerning direct expropriations, the ECtHR decisions coincide with the views of the ILC, investment tribunals and the $\mathrm{HRC}$, and therefore consider them as instantaneous acts not amounting to a continuous deprivation of the right at hand. ${ }^{35}$ In this context, the extinguished European Commission on Human Rights had analysed several complaints regarding expropriations during and after the Second World War. In all of them, the Commission considered it lacked jurisdiction ratione temporis considering, as noted above, the instantaneous nature of these acts. ${ }^{36}$

32 European Court of Human Rights, ECtHR, Papamichalopoulos and others v. Greece, Application 14556/89, Judgment, 24 June 1993, para. 45. Available at: http://hudoc.echr. coe.int/eng?i=001-57836

33 European Court of Human Rights, ECtHR, Loizidou v. Turkey, Application 15318/89, Judgment, 18 December 1996, para. 46. Available at: http://hudoc.echr.coe.int/ eng?i=001-58007

34 European Court of Human Rights, ECtHR, Hutten-Czapska v. Poland, Application 35014/97, Judgment, 19 June 2006, paras. 152-153. Available at: http://hudoc.echr.coe. int/eng?i=001-75882

35 European Court of Human Rights, ECtHR, Almeida Garrett, Mascarenhas Falcão and others v. Portugal, Application 29813/96 and 30229/96, Judgment, 11 January 2000, para. 86. Available at: http://hudoc.echr.coe.int/eng?i=001-58417

36 European Court of Human Rights, ECtHR, August Szechenyi v. Hungary, Application 21344/93, Commission Decision, Second Chamber, 30 June 1993. Available at: http:// hudoc.echr.coe.int/eng?i=001-1618. European Court of Human Rights, ECtHR, Firma Brauerei Feldschlösschen Ferdinand Geidel KG, Charlotte Davies, Gerhard Geidel, the estate of Louise Geidel and Margarete Landgraf v. Germany, Application 19918/92, Commission Decision, Second Chamber, 24 February 1997. Available at: http://hudoc.echr.coe.int/ eng?i=001-3483. European Court of Human Rights, ECtHR, Oda Kremer-Viereck and Helge Viereck v. Germany, Application 34197/96, Commission Decision, First Chamber, 21 May 1998. Available at: http://hudoc.echr.coe.int/eng?i=001-4276 
The ECtHR has also confirmed this position, for instance, in the case of Preussische Treuhand GmbH \& Co. KG a.A. v. Poland ${ }^{37}$ Interestingly, in the case of Almeida Garret, Mascarenhas Falcão and others v. Portugal, the ECtHR dealt with a situation similar to the one that constitutes the raison d'etre of the present article. It referred to the lack of payment, from the Portuguese Government, of compensation provided through a decree enacted after the European Court of Human Rights entered into force. It was noted in this regard that,

While it is true that the Court is not empowered to examine questions linked to the deprivation of the property, such questions clearly being beyond its jurisdiction ratione temporis, the same does not apply to the delays in the assessment and payment of final compensation... the government continued to legislate on the subject after ratifying the Convention. ${ }^{38}$

Having reviewed how various international courts and tribunals have applied the doctrine of continuous acts in cases of expropriation, the following section will refer the Court's decision to uphold Panama's preliminary objection and the dissenting opinion appended by Judge Ferrer Mac-Gregor.

\section{The Courts' DeCision to UPHOLd PANAMA'S PRELIMINARY OBJECTION}

In the course of the proceedings before the Inter-American Commission on Human Rights, Panama raised the objection ratione temporis to its jurisdiction. It referred as to its lack of jurisdiction to decide on the merits of the claim regarding Panama's international responsibility, for the failure to compensate the indigenous communities for stripping and flooding of their territories due to the construction of a hydroelectric dam from 1972 to 1976.

37 European Court of Human Rights, ECtHR, Preussische Treuhand GmbH \& Co. KGa.A. v. Poland, Application 47550/06, Judgment, 7 October 2008, para. 56. Available at: http:// hudoc.echr.coe.int/eng?i=001-88871

38 European Court of Human Rights, ECtHR, Almeida Garrett, Mascarenhas Falcão and others v. Portugal, Application 29813/96 and 30229/96, Judgment, 11 January 2000, para. 43. Available at: http://hudoc.echr.coe.int/eng?i=001-58417 
Panama's argument was based on the fact that it ratified the ACHR on 5 June 1978, while accepting the IACtHR's contentious jurisdiction on 9 May 1990. Consequently, it contended that in light of the prohibition to apply treaties retroactively, a manifest lack of jurisdiction exists. ${ }^{39}$

The Commission decided in its report on the merits not to uphold this objection. Its decision was based on the fact that, the obligations emerging from the expropriation of the indigenous' territories, i.e., compensation and recognition of the rights to the land granted, persist after the entry into force of the ACHR for Panama. This was moreover complemented by subsequent acts from the State reaffirming these obligations. ${ }^{40}$

\section{A. The Reasoning of the Court}

At the beginning of its analysis on the objection, the Court noted that both, the Inter-American Commission on Human Rights and the victims based their argument on the continuous character of the lack of payment of compensation ${ }^{41}$ in the Case of the Moiwana Community v. Suriname. ${ }^{42}$ The Court therefore noted that, it should determine whether it is competent to assess (a) the alleged lack of payment of compensation agreed a decade before Panama accepted the Court's contentious jurisdiction; and (b) if the amount of compensation is adequate to redress the alleged wrong occasioned by the construction of the hydroelec-

39 Inter-American Court of Human Rights, IACtHR, Case of Indigenous Communities Kuna of Madungandí and Emberá of Bayano and their Members v. Panama, Series C 284, Preliminary objections, merits, reparations and costs, Judgment of 14 October 2014, para. 24. Available at: http://www.corteidh.or.cr/docs/casos/articulos/seriec_284_esp.pdf

40 Inter-American Court of Human Rights, IACtHR, Kuna Indigenous People of Madungandi and Emberá Indigenous People of Bayano and their Members v. Panamá, Case 12354, Merits, Report 125/12, para. 90. Available at: http://www.oas.org/en/iachr/decisions/ court/12.354FondoEng.pdf

41 Inter-American Court of Human Rights, IACtHR, Case of Indigenous Communities Kuna of Madungandi and Emberá of Bayano and their Members v. Panama, Series C 284, Preliminary objections, merits, reparations and costs, Judgment of 14 October 2014, para. 29. Available at: http://www.corteidh.or.cr/docs/casos/articulos/seriec_284_esp.pdf

42 Inter-American Court of Human Rights, IACtHR, Case of the Moiwana Community v. Suriname, Series C 124, Preliminary objections, merits, reparations and costs, Judgment of 15 June 2005. Available at: http://www.corteidh.or.cr/docs/casos/articulos/seriec_124_ing. pdf 
tric. Nonetheless, both issues required a previous examination of the continuous character vel non of the lack of payment. ${ }^{43}$

In that regard, the Court began by distinguishing the Case of the Moiwana Community v. Suriname from the situation under analysis. It, thus, noted the former referred as to the forced displacement of a tribal community, which had not been replaced in alternative lands. The Court found a violation of Article 21 ACHR (right to property), since the situation of violence deprived them from the use of their traditional lands. ${ }^{44}$ On the contrary, the case at hand is based on different facts. The indigenous communities do not have the possibility to return to their traditional lands, were replaced in alternative lands and, the continuous violation was only submitted with regard to the lack of payment and not the deprivation of property. ${ }^{45}$

In addition, the Court took into account its decision in García Lucero and other v. Chile, ${ }^{46}$ by noting that:

the Tribunal has established in a recent case that 'the integral nature or individuali[s]ation of the reparation can only be evaluated based on an examination of the facts that gave raise to the harm and their effects', and that in consequence, in case of lacking jurisdiction over the fact that generated the harm, 'is unable to analy[s]e these facts per se, or their effects, or the measures of reparation awarded in this regard. ${ }^{47}$

43 Inter-American Court of Human Rights, IACtHR, Case of Indigenous Communities Kuna of Madungandi and Emberá of Bayano and their Members v. Panama, Series C 284, Preliminary objections, merits, reparations and costs, Judgment of 14 October 2014, para. 33. Available at: http://www.corteidh.or.cr/docs/casos/articulos/seriec_284_esp.pdf

44 Inter-American Court of Human Rights, IACtHR, Case of Indigenous Communities Kuna of Madungandí and Emberá of Bayano and their Members v. Panama, Series C 284, Preliminary objections, merits, reparations and costs, Judgment of 14 October 2014, para. 29. Available at: http://www.corteidh.or.cr/docs/casos/articulos/seriec_284_esp.pdf

45 Inter-American Court of Human Rights, IACtHR, Case of Indigenous Communities Kuna of Madungandí and Emberá of Bayano and their Members v. Panama, Series C 284, Preliminary objections, merits, reparations and costs, Judgment of 14 October 2014, para. 36. Available at: http://www.corteidh.or.cr/docs/casos/articulos/seriec_284_esp.pdf

46 Inter-American Court of Human Rights, IACtHR, Case of García Lucero et al. v. Chile, Series C 267, Preliminary objections, merits and reparations, Judgment of 28 August 2013, paras. 28-44. Available at: http://www.corteidh.or.cr/docs/casos/articulos/seriec_267_ing. pdf

47 Inter-American Court of Human Rights, IACtHR, Case of Indigenous Communities Kuna of Madungandí and Emberá of Bayano and their Members v. Panama, Series C 284, Preliminary objections, merits, reparations and costs, Judgment of 14 October 2014, para. 37. Available at: http://www.corteidh.or.cr/docs/casos/articulos/seriec_284_esp.pdf 
Based on these motives, the Court concluded that the alleged lack of payment of the right to property refers to a disagreement with respect to the payment of compensation acknowledged by Panama in decrees and agreements from 1971, 1976, 1977, and 1980. All these documents were signed before 1990, i.e. the year in which Panama accepted the IACtHR's contentious jurisdiction. None of them, therefore, are within the jurisdiction ratione temporis of the Court.$^{48}$ In consequence, the Court could not proceed to analyse in the merits of the issues related to the flooding of the indigenous communities' territory, namely, the lack of payment of compensation.

\section{B. Judge Ferrer Mac-Gregor partial dissenting opinion}

Judge Eduardo Ferrer Mac-Gregor Poisot, voted against the Court's finding regarding its lack of jurisdiction ratione temporis. He thus appended a partial dissenting opinion to the judgment. For him "the Court should have dismissed said preliminary objection raised by the State and proceed to the merits of the dispute, taking into consideration that in the present case we are not before isolated acts of an instant nature, but before a continuous situation (a composite act) concerning the failure to pay compensation."'49

In order to sustain his disagreement, Judge Ferrer MacGregor referred to (i) the jurisprudential development of Article 21 from the perspective of the collective property of indigenous communities; (ii) the limitations to the right to collective property of indigenous communities in the Inter-American system; (iii) the right to payment of just compensation in cases of expro-

48 Inter-American Court of Human Rights, IACtHR, Case of Indigenous Communities Kuna of Madungandi and Emberá of Bayano and their Members v. Panama, Series C 284, Preliminary objections, merits, reparations and costs, Judgment of 14 October 2014, para. 38. Available at: http://www.corteidh.or.cr/docs/casos/articulos/seriec_284_esp.pdf

49 Inter-American Court of Human Rights, IACtHR, Case of Indigenous Communities Kuna of Madungandi and Emberá of Bayano and their Members v. Panama, Series C 284, Judgment of 14 October 2014, partial dissenting opinion of Judge Eduardo Ferrer Mac-Gregor Poisot, para. 4. Available at: http://www.corteidh.or.cr/docs/casos/articulos/ seriec_284_esp.pdf 
priation as a continuous violation; and (iv) the lack of payment of compensation as a continuous violation in the case of the indigenous communities Kuna of Madungandí and Emberá of Bayano.

In (iii), Judge Ferrer Mac-Gregor notes that "the Court in its diverse considerations when deciding the preliminary objection with respect to the 'alleged lack of jurisdiction ratione temporis' decided not to enter in the core discussion on the matter, in the sense of defining the meaning and scope of the international standards on what a continuous violation is, and how said standards are applicable to the present case." ${ }^{50} \mathrm{He}$, therefore, embarks in an analysis of the doctrine of continuous violations in international law, aiming to assess whether the lack of payment of compensation constitutes a continuous violation.

Throughout (iii), Judge Ferrer Mac-Gregor refers to the ILC's articles on state responsibility, and the jurisprudence of investment tribunals, ECtHR, HRC, and the Court itself. ${ }^{51} \mathrm{He}$ pays special attention to the jurisprudence of the ECtHR with respect to the right to property in the context of its jurisdiction ratione temporis and from said evaluation he concludes, "the abovementioned cases demonstrate us that the determination on whether an act is continuous, should be done on a case by case basis." 52

Hence, and relying on the facts of the case at hand (and especially the decrees and agreements signed by the government and the indigenous communities), judge Ferrer Mac-Gregor concludes the situation can be considered as a composite act. In

50 Inter-American Court of Human Rights, IACtHR, Case of Indigenous Communities Kuna of Madungandí and Emberá of Bayano and their Members v. Panama, Series C 284, Judgment of 14 October 2014, partial dissenting opinion of Judge Eduardo Ferrer Mac-Gregor Poisot, para. 31. Available at: http://www.corteidh.or.cr/docs/casos/articulos/ seriec_284_esp.pdf

51 Some of these decisions correspond to those presented in the previous section of this paper.

52 Inter-American Court of Human Rights, IACtHR, Case of Indigenous Communities Kuna of Madungandí and Emberá of Bayano and their Members v. Panama, Series C 284, Judgment of 14 October 2014, partial dissenting opinion of Judge Eduardo Ferrer Mac-Gregor Poisot, para. 51. Available at: http://www.corteidh.or.cr/docs/casos/articulos/ seriec_284_esp.pdf 
that sense, the violation extends over the entire period of time starting with the first of the actions and lasts for as long as these actions are repeated and remain not in conformity with the international obligation. ${ }^{53}$ In his view, the problem with regard to the lack of payment of compensation to the indigenous communities has been consistently recognised by Panama since the issuance of the 1971 decree,${ }^{54}$ and in different and subsequent moments, demonstrating the continuous nature of the facts. ${ }^{55}$

By the same token, Judge Ferrer Mac-Gregor notes that when analysing the preliminary objection, the Court decided not to assess whether the facts constituted a continuous situation. The majority opted for implicitly noting it was not. This explains why the majority agreed to refer to the Case of García Lucero and others $v$. Chile, ${ }^{56}$ a case that is not applicable to the one at hand, since the former did not referred to a continuous situation, ${ }^{57}$ as the Court itself noted in their decision. ${ }^{58}$ As for the reference to the Case of the Moiwana Community v. Suriname, ${ }^{59}$ Judge Ferrer Mac-Gregor underlines that,

53 Draft Articles on Responsibility of States for Internationally Wrongful Acts, Yearbook of the International Law Commission 2001, Volume II (part two), A/CN.4/SER.A/2001/ Add.1 (Part 2), 62. Available at: http://legal.un.org/ilc/publications/yearbooks/english/ ilc_2001_v2_p2.pdf

54 See supra section II.

55 Inter-American Court of Human Rights, IACtHR, Case of Indigenous Communities Kuna of Madungandí and Emberá of Bayano and their Members v. Panama, Series C 284, Judgment of 14 October 2014, partial dissenting opinion of Judge Eduardo Ferrer Mac-Gregor Poisot, para. 73. Available at: http://www.corteidh.or.cr/docs/casos/articulos/ seriec_284_esp.pdf

56 Inter-American Court of Human Rights, IACtHR, Case of García Lucero et al. v. Chile, Series C 267, Preliminary objections, merits and reparations, Judgment of 28 August 2013. Available at: http://www.corteidh.or.cr/docs/casos/articulos/seriec_267_ing.pdf

57 Inter-American Court of Human Rights, IACtHR, Case of Indigenous Communities Kuna of Madungandi and Emberá of Bayano and their Members v. Panama, Series C 284, Judgment of 14 October 2014, partial dissenting opinion of Judge Eduardo Ferrer Mac-Gregor Poisot, para. 76. Available at: http://www.corteidh.or.cr/docs/casos/articulos/ seriec_284_esp.pdf

58 Inter-American Court of Human Rights, IACtHR, Case of García Lucero et al. v. Chile, Series C 267, Preliminary objections, merits and reparations, Judgment of 28 August 2013, para. 34. Available at: http://www.corteidh.or.cr/docs/casos/articulos/seriec_267_ing.pdf

59 Inter-American Court of Human Rights, IACtHR, Case of the Moiwana Community v. Suriname, Series C 124, Preliminary objections, merits, reparations and costs, Judgment of 15 June 2005. Available at: http://www.corteidh.or.cr/docs/casos/articulos/seriec_124_ing. pdf 
while it is true that the present case is not exactly equal to that, is pertinent to clarify that according to the proven facts of the present case, according to international law and especially international human rights law, there were enough decisions - that have tried to highlight [in the present opinion] - that the application of the pro persona principle, would have led this Inter-American Tribunal to a different decision regarding this preliminary objection, especially considering that the alleged failure to comply with the payment of compensation is related to the stripping and flooding of ancestral territories of indigenous communities. ${ }^{60}$

60 Inter-American Court of Human Rights, IACtHR, Case of Indigenous Communities Kuna of Madungandi and Emberá of Bayano and their Members v. Panama, Series C 284, Judgment of 14 October 2014, partial dissenting opinion of Judge Eduardo Ferrer Mac-Gregor Poisot, para. 77. Available at: http://www.corteidh.or.cr/docs/casos/articulos/ seriec_284_esp.pdf 
CONCLUSION

The Court has had referred to the scope of its jurisdiction ratione temporis in relation to continuous violations in several opportunities. ${ }^{61}$ Nevertheless, in none of these instances an analysis had to be made regarding the failure to pay compensation deriving from an expropriation of property taking place before the ACHR has entered into force for a state and it had accepted the Court's contentious jurisdiction. Consequently, the Case of Indigenous Communities Kuna of Madungandi and Emberá of Bayano and its members v. Panama was a perfect opportunity for the Court set forth the scope of its jurisdiction ratione temporis, in this type of situations.

Expropriation constitutes an instantaneous act under international law, as the jurisprudence of various international courts and tribunals demonstrates. Likewise, the fact that compensation was not granted, does not transform expropriation in a continuous violation. Failure to compensate is but one of the effects of the act of expropriation. It is not relevant thus for the characterisation of the act as either instantaneous or continuous. In that order of ideas, one might conclude that the Court's conclusion as to its jurisdiction ratione temporis in the present case was correct. It did not, however (and as noted by judge Ferrer Mac-Gregor), fully appreciate the facts of the case and did not take into account important decisions from international courts and tribunals ${ }^{62}$ that would have led to a different conclusion. It

61 Inter-American Court of Human Rights, IACtHR, Case of Cantos v. Argentina, Series C 97, Merits, reparations and costs, Judgment of 28 November 2002. Available at: http:// www.corteidh.or.cr/docs/casos/articulos/seriec_97_ing.pdf. Inter-American Court of Human Rights, IACtHR, Case of Alfonso Martín del Campo Dodd v. United Mexican States. Series C 113, Preliminary objections, Judgment of 3 September 2004. Available at: http://www.corteidh.or.cr/docs/casos/articulos/seriec_113_ing.pdf. Inter-American Court of Human Rights, IACtHR, Case of Serrano-Cruz Sisters v. El Salvador, Series C 120, Merits, reparations and costs Judgment of 1 March 2005. Available at: http://www. corteidh.or.cr/docs/casos/articulos/seriec_120_ing.pdf. Inter-American Court of Human Rights, IACtHR, Case of Gomes Lund and others (Guerrilha do Araguaia) v. Brazil, Series C 219, Preliminary objections, merits, reparations and costs, Judgment of 24 November 2010. Available at: http://www.corteidh.or.cr/docs/casos/articulos/seriec_219_ing.pdf

62 European Court of Human Rights, ECtHR, Almeida Garrett, Mascarenhas Falcão and others v. Portugal, Application 29813/96 and 30229/96, Judgment, 11 January 2000, para. 
is in this specific regard that the Court's conclusion as to its lack of jurisdiction ratione temporis was incorrect.

In two decisions issued by the ECtHR, Portugal (Almeida Garret, Mascarenhas Falcão y and others) ${ }^{63}$ and Poland (Broniowski) ${ }^{64}$ were found internationally responsible, respectively, for the breach of Article 1 (protection of property) of the Protocol to the Convention for the Protection of Human Rights and Fundamental Freedoms. Both states expropriated property of individuals without providing compensation, before said Protocol entered in force. In spite of this fact, through certain commitments made by these states with regard to compensation after the Protocol's entry into force, the ECtHR concluded to hold jurisdiction and proceed to the merits of the claims.

In the case at hand, three facts deserve special attention. First, from the moment that the expropriation took place, Panama recognised the indigenous communities' right to compensation. ${ }^{65}$ Second, in 1980, i.e., after Panama's ratification of the ACHR, an agreement was reached between the indigenous communities and the government with regard to the payment of compensation. ${ }^{66}$ Third, and as noted by judge Ferrer Mac-Gregor in his dissenting opinion, Article 21 of the ACHR permits the deprivation of property if inter alia payment of just compensation is made. In light of these three aspects, it is submitted that Panama has unilaterally renewed its commitment to pay compensation, once the ACHR has already entered into force for it. Consequently,

43. Available at: http://hudoc.echr.coe.int/eng?i=001-58417. European Court of Human Rights, ECtHR, Broniowski v. Poland, Application 31443/96, Judgment, 22 June 2004, para. 162. Available at: http://hudoc.echr.coe.int/eng?i=001-61828

63 European Court of Human Rights, ECtHR, Almeida Garrett, Mascarenhas Falcão and others v. Portugal, Application 29813/96 and 30229/96, Judgment, 11 January 2000, para. 43. Available at: http://hudoc.echr.coe.int/eng?i=001-58417.

64 European Court of Human Rights, ECtHR, Broniowski v. Poland, Application 31443/96, Judgment, 22 June 2004, para. 162. Available at: http://hudoc.echr.coe.int/eng?i=001-61828

65 European Court of Human Rights, ECtHR, Almeida Garrett, Mascarenhas Falcão and others v. Portugal, Application 29813/96 and 30229/96, Judgment, 11 January 2000, para. 43. Available at: http://hudoc.echr.coe.int/eng?i=001-58417.

66 Inter-American Court of Human Rights, IACtHR, Kuna Indigenous People of Madungandí and Emberá Indigenous People of Bayano and their Members v. Panamá, Case 12354, Merits, Report 125/12, para. 96. Available at: http://www.oas.org/en/iachr/decisions/ court/12.354FondoEng.pdf 
Panama should comply with said obligation to pay compensation from the moment it signed the agreement in 1980. Failure to comply with said obligation constitutes a continuous violation over the whole period of time the failure extends. As a result, the Court is competent ratione temporis to assess the merits of the claim.

The fact that Panama did not accept the Court's contentious jurisdiction until 1990 does not affect the previous conclusion. It is true that, in accordance with the non-retroactivity principle, the Court has to consider the date of acceptance by states of its contentious jurisdiction in order to declare their international responsibility.$^{67}$ However, it is also true that states are obliged to respect and ensure the rights protected by the ACHR from the date on which it was ratified ${ }^{68}$ Since Panama's breach is of a continuous character and the failure to compensate has extended until present, the Court is competent.

Arriving to this conclusion with regard to the Court's decision (whose correctness is open to be discussed) could not have been possible without an assessment of the doctrine of continuous violations in the context of the jurisdiction ratione temporis of international courts and tribunals. It is in this sense that the dissenting opinion of Judge Ferrer Mac-Gregor is valuable (not in the way he defines the situation, i.e., a composite act) ${ }^{69}$ as he

67 Inter-American Court of Human Rights, IACtHR, Case of the Moiwana Community v. Suriname, Series C 124, Preliminary objections, merits, reparations and costs, Judgment of 15 June 2005, para. 28. Available at: http://www.corteidh.or.cr/docs/casos/articulos/ seriec_124_ing.pdf

68 Inter-American Court of Human Rights, IACtHR, Case of the Rio Negro Massacres v. Guatemala, Series C 250, Preliminary objections, merits, reparations and costs, Judgment of 4 September 2012, para. 36. Available at: http://www.corteidh.or.cr/docs/casos/ articulos/seriec_250_ing.pdf

69 For Judge Ferrer Mac-Gregor, the various facts of the case can be categorised as composite acts, i.e., the violation of an international obligation through a series of actions or omissions defined in aggregate as wrongful. Inter-American Court of Human Rights, IACtHR, Case of Indigenous Communities Kuna of Madungandi and Emberá of Bayano and their Members v. Panama, Series C 284, Judgment of 14 October 2014, partial dissenting opinion of Judge Eduardo Ferrer Mac-Gregor Poisot, para. 72. Available at: http:// www.corteidh.or.cr/docs/casos/articulos/seriec_284_esp.pdf. It is submitted that the obligation breached by Panama is not constituted by a series of acts that taken together constitute the wrongful act. On the contrary, it is one act, i.e., the expropriation effected by Panama of the indigenous territories and which entails a duty to pay compensation, which constitutes the continuous violation in the present case. 
takes adequate account of the views of other international courts and tribunals on the subject. ${ }^{70}$

Hence, this is one of the judgments in which a dissenting opinion tends to be more useful than the majority decision. ${ }^{71}$ It has clarified certain aspects with regard to the continuous violations doctrine, in the context of expropriation. Similarly, it has implicitly shown how the discussion on the matter took place within the courtroom. Moreover, it has replied to the Court's reasoning and its choice of basing said reasoning in a previous decision with a different factual background and where the title to property was not revoked. In addition, and based on said reply to the IACtHR's reasoning, this partial dissenting opinion has a caution role, in the sense that it can narrow down the scope of the decision in terms of its ratio decidendi, the factual circumstances to which it applies, and the understanding as to how far the legal principle set forth by the Court can be applied in subsequent decisions. Lastly and as already noted, it has taken account of decisions from other international courts and tribunals on the matter; this is something the Court was expected to do in its judgment, considering the ample number of decisions that had dealt with this kind of situation.

In sum, Judge Ferrer Mac-Gregor dissenting opinion leads one to conclude that the Court has missed an important opportunity to set forth the scope of its jurisdiction ratione temporis, with regard to expropriations and the obligations deriving from it for States. Few cases are brought before the Court each year (in addition to not receiving any other on expropriation so far). Hence the IACtHR should have, along with settling the dispute before it, pronounced on issues likely to happen in the region with a view of sending a clear message to states as to how they should act in the context of expropriations.

70 Thomas Buergenthal, Proliferation of International Courts and Tribunals: Is it Good or Bad?, 14 Leiden Journal of International Law, 2, 267-275, 274 (2001).

71 L. C. Green, International Court of Justice, Right of Asylum Case (Colombia/Peru), 4 The International Law Quarterly, 2, 229-239, 238 (1951). Available at: http://www.jstor.org/ stable/762845?seq=1\#page_scan_tab_contents 


\title{
BIBLIOGRAPHY
}

\author{
Journals
}

Altiparmak, Kerem, The Application of the Concept of Continuing Violation to the Duty to Investigate, Prosecute and Punish International Human Rights Law, 21-25 Turkish Yearbook of Human Rights, 3-50 (1999-2004). Available at: http:// papers.ssrn.com/sol3/papers.cfm?abstract_id=926281

Buergenthal, Thomas, Proliferation of International Courts and Tribunals: Is it Good or Bad?, 14 Leiden Journal of International Law, 2, 267-275 (2001).

Green, L. C., International Court of Justice, Right of Asylum Case (Colombia/Peru), 4 The International Law Quarterly, 2, 229-239 (1951). Available at: http://www. jstor.org/stable/762845?seq=1\#page_scan_tab_contents

\section{Briefs, documents, reports, yearbooks}

Draft Articles on Responsibility of States for Internationally Wrongful Acts, Yearbook of the International Law Commission 2001, Volume II (part two), A/ CN.4/SER.A/2001/Add.1 (Part 2). Available at: http://legal.un.org/ilc/publications/yearbooks/english/ilc_2001_v2_p2.pdf

Seventh Report on State Responsibility by Mr. Roberto Ago, Special Rapporteur - The Internationally Wrongful Act of the State, source of international responsibility, Yearbook of the International Law Commission 1978, Volume II (part one), A/CN.4/SER.A/1978/Add.1 (Part 1). Available at: http:// legal.un.org/docs/?path=../ilc/publications/yearbooks/english/ilc_1978_v2_ p1.pdf\&lang $=$ EFSR

\section{International treaties}

Organization of American States, OAS, American Convention on Human Rights, ACHR, Pact of San Jose, Costa Rica, 22 November 1969. Available at: http:// www.oas.org/dil/treaties_B-32_American_Convention_on_Human_Rights. htm

United Nations, UN, Optional Protocol to the International Covenant on Civil and Political Rights, adopted and opened for signature, ratification and accession by General Assembly resolution 2200A (XXI) of 16 December 1966, entry into force 23 March 1976, in accordance with Article 9, volume 999 UNTS, 302 (Treaty Series, United Nations, New York, Geneva, 1976). Available at: http://www.ohchr.org/EN/ProfessionalInterest/Pages/OPCCPR1.aspx, https:// treaties.un.org/doc/Publication/UNTS/Volume\%20999/v999.pdf

United Nations, UN, Vienna Convention on the Law of Treaties, done at Vienna on 23 May 1969, entered into force on 27 January 1980, vol. 1155 UNTS (Treaty Series, United Nations, New York, Geneva, 1969). Available at: http://legal. 
and Emberá of Bayano and its Members v. Panama

un.org/ilc/texts/instruments/english/conventions/1_1_1969.pdf

\section{Inter-American Court of Human Rights, IACtHR, cases}

Inter-American Court of Human Rights, IACtHR, Case of Alfonso Martín del Campo Dodd v. United Mexican States. Series C 113, Preliminary objections, Judgment of 3 September 2004. Available at: http://www.corteidh.or.cr/docs/ casos/articulos/seriec_113_ing.pdf

Inter-American Court of Human Rights, IACtHR, Case of Cantos v. Argentina, Series C 97, Merits, reparations and costs, Judgment of 28 November 2002. Available at: http://www.corteidh.or.cr/docs/casos/articulos/seriec_97_ing.pdf

Inter-American Court of Human Rights, IACtHR, Case of García Lucero et al. v. Chile, Series C 267, Preliminary objections, merits and reparations, Judgment of 28 August 2013. Available at: http://www.corteidh.or.cr/docs/casos/ articulos/seriec_267_ing.pdf

Inter-American Court of Human Rights, IACtHR, Case of Gomes Lund and others (Guerrilha do Araguaia) v. Brazil, Series C 219, Preliminary objections, merits, reparations and costs, Judgment of 24 November 2010. Available at: http:// www.corteidh.or.cr/docs/casos/articulos/seriec_219_ing.pdf

Inter-American Court of Human Rights, IACtHR, Case of Indigenous Communities Kuna of Madungandi and Emberá of Bayano and their Members $v$. Panama, Series C 284, Preliminary objections, merits, reparations and costs, Judgment of 14 October 2014. Available at: http://www.corteidh.or.cr/docs/ casos/articulos/seriec_284_esp.pdf

Inter-American Court of Human Rights, IACtHR, Case of Indigenous Communities Kuna of Madungandí and Emberá of Bayano and their Members v. Panama, Series C 284, Judgment of 14 October 2014, partial dissenting opinion of Judge Eduardo Ferrer Mac-Gregor Poisot. Available at: http://www.corteidh.or.cr/ docs/casos/articulos/seriec_284_esp.pdf

Inter-American Court of Human Rights, IACtHR, Case of Serrano-Cruz Sisters v. El Salvador, Series C 120, Merits, reparations and costs Judgment of 1 March 2005. Available at: http://www.corteidh.or.cr/docs/casos/articulos/ seriec_120_ing.pdf

Inter-American Court of Human Rights, IACtHR, Case of the Moiwana Community v. Suriname, Series C 124, Preliminary objections, merits, reparations and costs, Judgment of 15 June 2005. Available at: http://www.corteidh.or.cr/ docs/casos/articulos/seriec_124_ing.pdf

Inter-American Court of Human Rights, IACtHR, Case of the Río Negro Massacres v. Guatemala, Series C 250, Preliminary objections, merits, reparations and costs, Judgment of 4 September 2012. Available at: http://www.corteidh. or.cr/docs/casos/articulos/seriec_250_ing.pdf

Inter-American Court of Human Rights, IACtHR, Kuna Indigenous People of Madungandí and Emberá Indigenous People of Bayano and their Members $v$. Panamá, Case 12354, Merits, Report 125/12. Available at: http://www.oas.org/ 
en/iachr/decisions/court/12.354FondoEng.pdf

\section{International cases law}

European Court of Human Rights, ECtHR, Almeida Garrett, Mascarenhas Falcão and others v. Portugal, Application 29813/96 and 30229/96, Judgment, 11 January 2000. Available at: http://hudoc.echr.coe.int/eng?i=001-58417

European Court of Human Rights, ECtHR, August Szechenyi v. Hungary, Application 21344/93, Commission Decision, Second Chamber, 30 June 1993. Available at: http://hudoc.echr.coe.int/eng?i=001-1618

European Court of Human Rights, ECtHR, Broniowski v. Poland, Application 31443/96, Judgment, 22 June 2004. Available at: http://hudoc.echr.coe.int/ eng? $\mathrm{i}=001-61828$

European Court of Human Rights, ECtHR, Firma Brauerei Feldschlösschen Ferdinand Geidel KG, Charlotte Davies, Gerhard Geidel, the estate of Louise Geidel and Margarete Landgraf v. Germany, Application 19918/92, Commission Decision, Second Chamber, 24 February 1997. Available at: http://hudoc.echr. coe.int/eng? $i=001-3483$

European Court of Human Rights, ECtHR, Hutten-Czapska v. Poland, Application 35014/97, Judgment, 19 June 2006. Available at: http://hudoc.echr.coe. int/eng? $\mathrm{i}=001-75882$

European Court of Human Rights, ECtHR, Loizidou v. Turkey, Application 15318/89, Judgment, 18 December 1996. Available at: http://hudoc.echr.coe. int/eng?i=001-58007

European Court of Human Rights, ECtHR, Oda Kremer-Viereck and Helge Viereck v. Germany, Application 34197/96, Commission Decision, First Chamber, 21 May 1998. Available at: http://hudoc.echr.coe.int/eng?i=001-4276

European Court of Human Rights, ECtHR, Papamichalopoulos and others $v$. Greece, Application 14556/89, Judgment, 24 June 1993. Available at: http:// hudoc.echr.coe.int/eng?i=001-57836

European Court of Human Rights, ECtHR, Preussische Treuhand GmbH \& Co. KG a.A. v. Poland, Application 47550/06, Judgment, 7 October 2008. Available at: http://hudoc.echr.coe.int/eng?i=001-88871

Human Rights Committee under the Optional Protocol to the International Covenant on Civil and Political Rights, HRC, Armand Anton v. Algeria, UN Doc. CCPR/C/88/D/1424/2005, Admissibility, 20 December 2006. Available at: http://www.worldcourts.com/hrc/eng/decisions/2006.11.01_Anton_v_Algeria.htm

Human Rights Committee under the Optional Protocol to the International Covenant on Civil and Political Rights, HRC, E. and A.K. [Edith and Arpad Könye] v. Hungary, UN Doc. CCPR/C/50/D.520/1992, Admissibility, 7 April 1994. Available at: http://www.worldcourts.com/hrc/eng/decisions/1994.04.07_E_v_ Hungary.htm 
Human Rights Committee under the Optional Protocol to the International Covenant on Civil and Political Rights, HRC, Josef Bergauer et al. v. Czech Republic, UN Doc. CCPR/C/100/D/1748/2008, Admissibility, 28 October 2010. Available at: http://www.worldcourts.com/hrc/eng/decisions/2010.10.28_ Bergauer_v_Czech_Republic.pdf

Human Rights Committee under the Optional Protocol to the International Covenant on Civil and Political Rights, HRC, Patrick Holland v. Ireland, Covenant on Civil and Political Rights, UN Doc. CCPR/C/58/D593/1994, Admissibility, 8 June 1994. Available at: http://www.worldcourts.com/hrc/ eng/decisions/1996.10.25_Holland_v_Ireland.htm

Human Rights Committee under the Optional Protocol to the International Covenant on Civil and Political Rights, HRC, Simunek, Hastings, Tuzilova \& Prochazka v. Czech Republic, CCPR/C/54/D/516/1992, Views, 17 September 1991. Available at: http://wwwl.umn.edu/humanrts/undocs/html/516-1992. html, http://www.worldcourts.com/hrc/eng/decisions/1995.07.19_Simunek_v_ Czech_Republic.htm

\section{International arbitration cases law}

International Centre for Settlement of Investment Disputes, ICSID, MCI Power Group, L.C. and New Turbine, Inc. v. Ecuador, ARB/03/6, Award of 31 July 2007. Available at: http://www.italaw.com/sites/default/files/case-documents/ ita0500.pdf

International Centre for Settlement of Investment Disputes, ICSID, Mondev International Ltd. v. United States of America, ARB(AF)/99/2, Award of 11 October 2002. Available at: http://www.italaw.com/sites/default/files/casedocuments/ita1076.pdf

International Centre for Settlement of Investment Disputes, ICSID, Pac Rim Cayman LLC v. El Salvador, ARB/09/12, Decision on Jurisdictional Objections of 1 June 2012. Available at: http://www.italaw.com/sites/default/files/ case-documents/ita0935.pdf

International Centre for Settlement of Investment Disputes, ICSID, Railroad Development Corporation v. Guatemala, ARB/07/23, Second Decision on Objections to Jurisdiction, Decision of 18 May 2010. Available at: http://www. italaw.com/sites/default/files/case-documents/ita0704.pdf

International Centre for Settlement of Investment Disputes, ICSID, SGS Société Générale de Surveillance S. A. v. Philippines, ARB/02/6, Decision on Jurisdiction, Decision of 29 January 2004. Available at: http://www.italaw.com/cases/1018, http://www.italaw.com/sites/default/files/case-documents/ita0782.pdf

United Nations Commission on International Trade Law, UNCITRAL, Chevron Corporation (USA) \& Texaco Petroleum Corporation (USA) v. Ecuador, Paris Court of Appeal, PCA Case 34877, Interim Award of 1 December 2008. Available at: http://www.italaw.com/documents/Chevron-TexacovEcuadorInterimAward.pdf 
United Nations Commission on International Trade Law, UNCITRAL, Sergei Paushok CJSC Golden East Company \& CJSC Vostokneftegaz Company v. Mongolia, Award on Jurisdiction and Liability, Decision of 28 April 2011. Available at: http://www.italaw.com/sites/default/files/case-documents/ita0622.pdf

United Nations Commission on International Trade Law, UNCITRAL, Société Générale in respect of DR Energy Holdings Limited and Empresa Distribuidora de Electricidad del Este, S.A. v. Dominican Republic, London Court of International Arbitration, LCIA Case UN 7927, Preliminary Objections to Jurisdiction, Decision of 19 September 2008. Available at: http://www.italaw. $\mathrm{com} /$ sites/default/files/case-documents/ita0798.pdf 